\title{
종 설
}

\section{신기 능저하 환자에서의 항결핵제 투여}

연세대학교 의 과대학 내과학교실

\section{김 문 재·한 대 석}

\section{Antituberculous Drugs in Patients with Impaired Renal Function}

\author{
Moon Jae Kim, M.D. and Dae Suk Han, M.D. \\ Department of Internal Medicine, Yonsei University College of Medicine
}

대부분의 투여된 약믈들은 간과 신장을 통하여 담즙 이나 소변으로 배설된다. 이중에서 신장에서 주로 배 설되는 약제는 그 물리화학적 성상에 따라 신사구체 여 과나 신세노콴 분비과정을 거처 배출되므로 신기능 장 애가 있을 경우 적절한 용량 조절 투여가 없으면 약물 의 체내축젹에 따른 여러 부작용 및 독성을 유발할 수 있다.

\section{신기능저하 환자에서 약제사용 원칙}

신기능 장애로 인한 체내의 생화학적 변화는 약물의 생체이용률(bioavailability), 약동학 (pharmacokinetics), 단백결합능 (protein-binding) 등에 영향을 주어 투여된 약물의 약리학적 활성이 증가되거나 약제의 제 거 반감기 (elimination half-life)가 연장되기도 한다 1 3).

신기능의 정도는 사구체 여과율(glomerular filtration rate)을 측정함으로써 알 수 있으며 일반적으로 크레아티닌 제거율 (creatinine clearance, 이하 Ccr 로 약함)로 표시된다. $\mathrm{Ccr}$ 의 산출은 24 시간동안의 소변 을 수거하여 계산하는 방식이 정확하지 만 다음과 같은 간편한 환산공식으로도 혈청 크레아티닌 치로부터 대 략 산출할 수 있다.

$$
\mathrm{Ccr}(\mathrm{ml} / \mathrm{min})=\frac{(140-\text { 년령 }) \times \text { 체 중 }(\mathrm{kg})}{72 \times \text { 혈청 크레 아티닌 치 }}
$$

여자는 여기에 0.85 을 곱하면 되며, 정상 성인의 사 구체 여과윤, 즉 $\mathrm{Ccr}$ 은 $100 \sim 120 \mathrm{ml} / \mathrm{min}$ 정 도이다 ${ }^{1)}$.

한편, 악물의 일 반적인 투여방식은 초회에 일정한 혈
중 농도에 도달키 위한 부하량 투여 (loading dose)와 유효농도를 지속하기 위한 일정시간 간격으로 유지량 투여 (maintenance dose) 로 구분된다 ${ }^{1,2)}$. 또 신장기능 저하 환자에서의 약물의 투여방식은 다음 2 가지로 대 별된다 ${ }^{2,6)}$.

첫째 방식은 감량투여법 (dosage reduction method) 으로 투여 간격은 정상대로 하고 개별적인 투여량을 감량하는 방법이다. 이때 감량투여량=정상투여 량 $\times$ $\frac{\text { 환자의 } \mathrm{Ccr}}{\text { 정 상인의 } \mathrm{Ccr}}$ 으로 계산된다. 또 다른 방식은 간격연 장법 (interval extension method)으로 이것은 개별 투여량은 정상대로 하되 투여간격을 늘리는 방법이며 이때 투여 간격 $=$ 정 상 투여간격 $\times \frac{\text { 정 상인의 } \mathrm{Ccr}}{\text { 환자의 } \mathrm{Ccr}}$ 으로 표시될 수 있다. 그러나 대부분의 약물은 그 대사. 배 설 과정에 있어서 일부는 간으로 배설되고 나머지 전 부는 신장을 통하여 배출되거나 이와는 반대로 일부가 신장으로 배설되고 나머지가 간대사를 통한 담즙으로 배출된다. 따라서 실제적인 투여 계산방식은 감량투여 량 $=$ 정상투여량 $\times \frac{\mathrm{FE}(\mathrm{C}-1)+1}{1}$, 투여간격 $=$ 정상 투 여간격 $\times \frac{1}{\mathrm{FE}(\mathrm{C}-1)+1}$ 로 표시되고 여기서 $\mathrm{FE}$ 는 전 체 약물대사중 신장제거율, $\mathrm{C}$ 는 정상인의 $\mathrm{Ccr}$ 에 대 한 환자의 $\mathrm{Ccr}$ 비율이다호. 예를 들면 어떤 약물이 신 장으로 $80 \%$ 가 제거되고, 이 약제가 투여 딜 환자의 $\mathrm{Ccr}$ 이 정상의 $10 \%$ 로 감소되어 있다면 이때 감량투여량은 정상투여량 $\times \frac{0.8 \times(0.1-1)+1}{1}$ 이고 투여간격 연장은 정 상간격 $\times \frac{1}{0.8 \times(0.1-1)+1}$ 로 계산된다. 
2 가지의 다른 투여방식에 따른 효과의 비교연구는 아 직 확실하게 규명된 바 없으나. 부정맥 치료제와 같이 일정한 지속적인 농도가 필요한 경우는 감량투여법을 실시하고 항생제와 같이 최고 혈중농도 도달이 우선필 요한 경우는 간격연장법이 채택된달.

투석요법을 실시중인 환자에서는 투석에 따른 약제 의 손실도 고려하여 투석후 보충(postdialysis supplement)을 실시해야 된다. 약물의 투석제거율(dialysis clearance)은 약제의 분자량(molecular size), 수용 성, 단백 결합능, 투석막 제거율 (membrane clearance) 등에 의하여 결정되는 데, 대체로 물에 불용성이거나 단백결합능이 강할수록 투석제거율이 적으며 혈액투석 의 경우 500 dalton 이상의 분자량을 가진 약물은 투 석제거에 따른 손실은 거의 없다 ${ }^{244}$.

\section{신기능저하 환자에서 항결핵제 사용}

최근 투석요법 과 신장이식술의 발전으로 만성 신부 전 환자의 생 존율이 증가함에 마라 이들 환자들에서 병 발되는 질환에 대한 치료도 역시 중요하게 되었다. 만 성 신부전 환자는 세포성 면역기능의 저하로 감염질한 의 이환율이 높으며 장기 투석치료를 받고 있는 환자 에서 결핵의 발병율이 정상인보다 10 12배 높다고 보 고되고 있다 ${ }^{5,7)}$.

만성 신부전 환자에서 결핵의 증상은 요독증 자체에 따른 증후와 비슷하여 초기 진단이 쉽지 않으며 훙부 $\mathrm{X}$-선 사진에서도 비 전형적인 양상을 띄는 경우가 많 고 폐이외의 장기에 결핵 발생이 많아 임파선염, 골관 절 결핵 발병율이 높다 $\left.{ }^{5} 8\right)$. 더우기 세포성 면역기능의 저하로 이들 환자들에서 PPD 피내 반응이 잘 나타나 지 않으므로 진단이 어렵다. 따라서 만성 신부전증도 당뇨병, 악성 종양질환, 장기적인 부신피질제 사용시, 위절제 과거력 등과 같이 결핵 밭생의 위험그릅으로 포 함되어 예 방적 항결핵제 화학요법이 요구퇴는 것으로 간주되기도 한당.

신기능저하 환자예서 원인을 모르는 불명열이 지속 될 경우 결핵을 일단은 한번쫌 의심하고 치료적 진단 방법으로 신기능 정도에 며라 적절한 항결핵제의 투여 가 필요하기 도 하다 ${ }^{5,7,8)}$.

신장기능 저하 환자, 특히 투석치료를 받고 있는 경 우에 결핵치료에 쓰이는 약제틀을 이와 연관지어 살펴 보면 다음과 같다.

\section{Isoniazid (INH)}

$\mathrm{INH}$ 는 주로 간장에서 acetylation 과정으로 대사되
어 제거되고 $20 \%$ 미만이 소변으로 배설되어 신기능에 관계 없이 투여된다. 그러나 $\mathrm{INH}$ 의 지연대사형 (slow acetylator)의 경우 그 반감기가 10시간 정도로 연장 되기 대문에 경증이나 중등증의 신기능저하 환자에서 는 상용량 그대로 투여되나 지연대사형으로 $\mathrm{Ccr}<10$ $\mathrm{ml} / \mathrm{min}$ 인 말기신장질환 상태에서는 감량투여가 요구 된다 ${ }^{3,7)}$. 이때의 용량예 대해서 논란이 많으나 200 $300 \mathrm{mg} / \mathrm{day}$ 가 적절한 유효농도를 유지하는 것으로 보 고 되고 있다, ${ }^{5,11)}$. 한편 신속대사형 (fast acetylator) 인 환자는 말기신장질환 상태일 경우에도 상용량이 그 대로 사용된다9,11).

또 만성 신부전증 환자에서는 요독증상으로 영양상 태가 불량하여 INH 투여에 따른 말초 신경염의 발생 위험이 높으므로 반드시 pyridoxine 의 병합투여가 필 요하다 ${ }^{7,10)}$.

한편 $\mathrm{INH}$ 는 분자량이 137 dalton 이고 단백결합능 이 약하기 때문에 혈액투석으로 상당량이 제거되므로 투석후 반드시 보충투여 $(3 \mathrm{mg} / \mathrm{kg})$ 가 필요하다.

\section{Rifampicin(RMP)}

$\mathrm{RMP}$ 은 간혹 간질성 신염 (interstitial nephritis) 에 의한 급성 신부전을 유발하기도 하지만 신기능저하 한자에서 신기능에 관계없이 안전하게 쓸수 있는 약물 이다. 투여된 $\mathrm{RMP}$ 의 거의 대부분이 간대사 과정을 거쳐 답즙으로 배설되고 $15 \%$ 미만이 소변으로 배출되 기 때문이다. 그러트로 심하게 긴행뒨 신부전 환자에 서도 용량의 조절이 킬요없이 상용량 그대로 사용된 닥,12). 도 분자량이 823 dalton 이고 단백결합능이 강 하기 매문에 혈액투석이나 복막투셕으로 별로 제거되 지 않고 투석후 보충투여가 필요 없닻,13).

\section{Ethambutol (EMB)}

$\mathrm{EMB}$ 는 투여 량의 65 $80 \%$ 가 그대로 신장을 통하여 배설되고 나머지가 대변으로 배출튄다. 따라서 중등도 이상의 신기능 장애 환자에 서는 용량 조절이 반드시 필 요하다 ${ }^{3)}$. Ccr 이 $10 \sim 50 \mathrm{ml} / \mathrm{min}$ 환자는 상용량 (15 $25 \mathrm{mg} / \mathrm{kg} / \mathrm{day}$ )의 $50 \%$ 정도로 감량 투여하거나 투여 간격을 매 36 시간 겅도로 늘리 는 것이 좋다. 또 $\mathrm{Ccr}$ 이 $10 \mathrm{ml} / \mathrm{min}$ 이하인 경 우는 상용량을 $75 \%$ 감량 투여하 거나 투여 간격을 태 48시간 정도로 늘리는 것이 필요 하다. $\mathrm{EMB}$ 는 감량투여 방식보다는 투여간격 연 장법 이 권장된다. $\mathrm{EMB}$ 는 분자량이 204 dalton 이고 단백 결합능이 약하므로 혈액투석이나 복막투석으로 투여량 의 $35 \%$ 정도가 제거된다. 따라서 투석후 이에 따른 보 
Table 1. Adjustment of Antituberculous Drugs for Renal Failure

\begin{tabular}{|c|c|c|c|c|c|c|c|}
\hline \multirow{3}{*}{ Drug } & \multirow{3}{*}{$\underset{\text { Routes }}{\text { Elimination }}$} & \multirow{3}{*}{$\begin{array}{l}\text { Half-life(h) } \\
\text { (Normal/ESRD) }\end{array}$} & \multirow{3}{*}{ Method } & \multirow{2}{*}{\multicolumn{3}{|c|}{$\frac{\text { Adjustment for renal failure }}{\operatorname{GFR}(\mathrm{ml} / \mathrm{min})}$}} & \multirow{3}{*}{$\begin{array}{l}\text { Postdialysis } \\
\text { supplement }\end{array}$} \\
\hline & & & & & & & \\
\hline & & & & $>50$ & $10 \sim 50$ & $<10$ & \\
\hline Isoniazid & $\begin{array}{l}\text { Hepatic } \\
\text { Renal }\end{array}$ & $\begin{array}{c}\text { Slow acetylator } \\
2 \sim 4 / 10 \\
\text { Rapid acetylator } \\
0.5 \sim 1.5 / 2\end{array}$ & D & 100 & 100 & $66 \sim 75$ & $\operatorname{Yes}(\mathrm{H}, \mathrm{P})$ \\
\hline Rifampin & Hepatic & $2 \sim 5 / 2 \sim 5$ & I & None & None & None & $\mathrm{No}(\mathrm{H})$ \\
\hline Ethambutol & Renal & $4 / 7 \sim 5$ & I & 24 & $24 \sim 36$ & 48 & $\operatorname{Yes}(\mathrm{H}, \mathrm{P})$ \\
\hline Streptomycin & Renal & $2.5 / 100$ & I & 24 & $24 \sim 72$ & $72 \sim 96$ & $\operatorname{Yes}(\mathrm{H})$ \\
\hline
\end{tabular}

* Abbreviations: ESRD=End-stage renal disease; $G F R=$ Glomerular filtration rate; $D=$ Dosage reduction method; $\mathrm{I}=$ Interval extension method; $\mathrm{H}=$ Hemodialysis; $\mathrm{P}=$ Peritoneal dialysis

** Adjustment by methods: \% of normal dose in " $\mathrm{D}$ "; Interval hours in "I"

충투여 $(5 \mathrm{mg} / \mathrm{kg})$ 가 필요하다. $\mathrm{EMB}$ 를 사용할 경 우는 $2 \sim 3$ 일 간격으로 혈중 농도률 자주 측정해보는 것이 좋 다 ${ }^{3,14)}$. 혈액투석 환자에서는 실제로 투석후 보충량을 고려할 필요없이 매 투석시 4 6 시간전에만 $\mathrm{EMB}$ 를 복용토록 하고 주 3 희 투석시에 는 투석전 $25 \mathrm{mg} / \mathrm{kg}$, 주 2 회 투석시에는 $45 \mathrm{mg} / \mathrm{kg}$, 주 1회 투석시에는 $90 \mathrm{mg} /$ $\mathrm{kg}$ 을 투석하는 방법이 권장되기도 한다무12).

\section{Pyrazinamiảe (PZA)}

현재까지 PZA 의 인켸내 익력학적 성상에 관해서는 자세히 규명되지 않고 있어 항결핵요법시 그 사용량에 대해서는 추천 용량이 다양하다. 더우기 $\mathrm{PZA}$ 의 배출 기전이 주로 신장을 통한 배설이므로 신질환자에서 용 량을 조절해야 된다는 견해하의 대부분 간에서 $\mathrm{PZA}$ 의 대사가 이루어지므로 신기능 정도와 관계없이 상용량 그대로 사용해도 좋다는 상반된 견해7)가 있디.

최근 국내보고 ${ }^{14}$ 에 의하면 $\mathrm{PZA}$ 의 신장을 통한 배 설은 전체 $\mathrm{PZA}$ 배출의 $1 / 3$ 정도에 불과하므로 간기능 장애를 수반한 경우에 만 용량조절이 필요하고 또 4 6 시간의 혈액투석으로 $41 \sim 51 \%$ 가 제거되는 것으로 보 고되고 있다. 따라서 간기능이 정상일 경우 1 일 20 $35 \mathrm{mg} / \mathrm{kg}$ 을 투여하고 투석 직후에 는 용량보충을 시행 해야 되는 것으로 퀀장듸고 있다.

\section{Streptomycin (SM)}

Aminoglycoside 계열의 항생제는 거의 신장에서 신 사구체 여과로 배설되므로 신기능 장애환자에서의 이 들 약제의 사옹은 신중을 기해야 한다. 이중 $\mathrm{SM}$ 은 혈 중농도롤 측정하면서 투여용량을 조절하는 뎨 trough
혈중농도가 $2 \mu \mathrm{g} / \mathrm{ml}$ 을 넘지 않아야 한다. 보통투여간 격을 24 72시간으로 연장하여 사용한다. 또 $\mathrm{SM}$ 은 복막투석시에는 $5 \sim 15 \mathrm{ml} / \mathrm{min}$ 가 제거되어 보충투여 가 필오 없으나 혈액투석에서는 $20 \sim 60 \mathrm{ml} / \mathrm{min}$ 정도 가 제거되어 투석후 용량보충을 해야 된다 ${ }^{3)}$. 매우 실제 적인 방법으로 $\mathrm{SM}$ 을 투석하는 날만 주되, 투석중의 heparinization 에 따른 근육녀 혈종이 생기는 것을 막 기 위하여 매 투석시 6시간 전에 $0.75 \mathrm{~g}$ 울 근육주사하 방법이 권장되기도 하고 매투석후에 $0.3 \sim 0.5 \mathrm{~g}$ 을 근 육주사하는 방법이 사용되기도 한다 ${ }^{8,11)}$.

이밖읙 결핵약제들에 대해서는 구체적인 신기능장애 한자에서 사용법이 제시된 바는 없다. cycloserine 은 신장을 통해서 그대로 배설되므로 신기능 장애시 용량 조절이 반드시 필요하고 단백결합률이 낮고 분자량이 102 dalton 으로 투석제거율이 높으므로 투석후 보충 이 필요할 것으로 사료된다 ${ }^{13)}$. Para-aminosalicylate (PAS)의 경우 대부분 신장으로 배설되고 정상적인 반 감기가 1 시간이지만 신기능 장애시는 최고 20 시간까지 연 장되는 것으로 보고되고 있다 ${ }^{13)}$. 이밖에 ethionamide 는 대부분 신장외 다른 경로로 배설되고 viomycin 과 capreomycin 은 신독성이 매우 강한 것으로 알려져 있 다 ${ }^{12)}$. 지금까지 상술한 중요 항결핵제의 사용 방법을 요약하먼 Table 1 과 같다.

한편, 신기능저하 환자에서 특별히 적합한 항결핵요 법이 보고된 바는 없고 일 반적인 결핵요법에 준한 regimen 과 치료기간이 제시되고 있다. 주로 INH, RMP, $\mathrm{PZA}$ 에 의한 3 제 병행요법이 비교적 안전하고 효과적 인 방법으로 보고되고 있담,14). 


\section{REFERENCES}

1) Coggings $\mathrm{CH}$, Bennett WM, Singer L: Drugs and kidney. In:Rose, B.D. eds. Pathophysiology of Renal Disease p711-732 New York McGraw-Hill, 1981

2) Bennett WM, Aronoff GR, Morrison G, et al: Drug prescribing in renal failure; dosing guidelines for adults. AmJ Kidney Dis 3:155, 1983

3) Anderson RJ, Schrier RW: Clinical Use of Drugs in Patients with Kidney and Liver Disease. p182-198 Philadelphia WB Saunders 1981

4) Golper TA: Drug use in uremia. In: Nissenson, AR, Fine RN eds. Dialysis Therapy p214211 St Louis CV Mosby, 1986

5) Andrew OT, Schoenfied PY, Hopewell PC, et al: Tuberculosis in patients with end-stage renal disease. Am J Med 68:59, 1980

6) Bennett WM, Muther RS, Parker RA, et al: Drug therapy in renal failure: dosing guidelines for adults. Ann Intern Med 93:62, 1980

7) Cuss FM, Carmcihael DJS, Linington A, Hul- me B: Tuberculosis in renal failure; a high incidence in patients born in the third world Clin Nephrol 25:129, 1986

8) Papadimitiou M, Memmos D, Metaxas P: Tuberculosis in patients on regular hemodialysis. Nephron 24:53, 1979

9) Reidenberg MD, Sher L, Cohen RV: Elimination of isoniazid in patients with impaired renal function. Am Rev Respir Dis 108:1426, 1973

10) Mitchison DA, Ellard GA: Tuberculosis in patients having dialysis. Br Med J 1:1533, 1980

11) Michison DA, Ellard GA: Tuberculosis in patients having dialysis. Br Med J 1:1186, 1980

12) Ross JD, Home NW: Modern Drug Treatment in Tubersulosis London: The Chest, Heart and Stroke Association, 1983

13) Drukker W, Parsons FM, Maher JF: Replacement of Renal Function in Dialysis p749-797 The Hague: Nihjoff, 1983

14) 김대중, 김성권, 이정상, 한용철, 이문호, 이선희, 신상구, 박찬웅 : 신기능장애 및 혈액투석환자에서 의 Pyrazinamide 의 약력학적 연구. 대한내과학 회잡지 31:1, 1986 